\title{
Alkyl-Chain-Length Dependence of Quaternary Ammonium Cation on Zn Deposition Morphology in Alkaline-based Electrolytes
}

Masahiro Shimizu, ${ }^{\mathrm{a}, \mathrm{b}, \mathrm{z}}$ Koichi Hirahara, ${ }^{\mathrm{a}}$ Yuki Ishida, ${ }^{\mathrm{a}}$ and Susumu Arai ${ }^{\mathrm{a}, \mathrm{b}, \mathrm{z}}$

${ }^{a}$ Department of Materials Chemistry, Faculty of Engineering, Shinshu University, 4-17-1 Wakasato, Nagano, 380-8553, Japan

${ }^{\mathrm{b}}$ Institute of Carbon Science and Technology, Shinshu University, 4-17-1 Wakasato, Nagano, 380-8553, Japan

${ }^{\mathrm{Z}}$ Corresponding author

Masahiro Shimizu

E-mail: shimizu@shinshu-u.ac.jp

Tel: +81-26-269-5627; Fax: +81-26-269-5627

Prof. Susumu Arai

E-mail: araisun@shinshu-u.ac.jp

Tel: +81-26-269-5413; Fax: +81-26-269-5432 


\begin{abstract}
The Influence of alkyl chain length in quaternary ammonium cations on electrochemical Zn growth morphology in alkaline-based electrolytes was systematically investigated under constant current density. Mossy structures that typically developed at low current density were mitigated in an electrolyte with $1 \mathrm{mM}$ octyltrimethylammonium chloride. By changing from octyl to decyl group in the surfactant, completely smooth deposition morphology was achieved. Electrochemical impedance spectroscopic analysis revealed that charge transfer resistance associated with Zn deposition increased with alkyl chain length. The obtained results indicate that bulky ammonium cations suppress excess electrodeposition due to the steric hindrance effect and thereby result in smooth morphology.
\end{abstract}




\section{Introduction}

Metallic $\mathrm{Zn}$ is an attractive negative electrode material due to not only its high theoretical capacity of $820 \mathrm{~mA} \mathrm{~h} \mathrm{~g}^{-1}$ based on deposition/stripping but also its low electrode potential of $-0.762 \mathrm{~V}$ vs. standard hydrogen electrode (SHE), and also its high abundance. ${ }^{1}$ Aqueous Zn-air batteries utilizing oxygen-reduction/evolution reactions, capable of eliminating concerning of ensuring safety, bring a high energy density of $1350 \mathrm{Wh} \mathrm{kg}^{-1}$, which can contribute to the establishment of a sustainable energy system. ${ }^{2}$ However, Zn-deposition/stripping associated with the large reversible capacity has serious issues that must be addressed. $\mathrm{Zn}$ deposition proceeds in form of mossy and dendrite structures in low and high current densities, respectively. ${ }^{3}$ Various efforts have been devoted to achieving smooth Zn deposition, such as the introduction anionexchange ionomer ${ }^{4}$, the use of organic electrolytes ${ }^{5}$ or surfactants in an aqueous system ${ }^{6,7}$, the optimization of substrates ${ }^{8}$, and the construction of matrix accommodating Zn shape changes ${ }^{9}$. In our previous studies, we demonstrated that a simple method, the addition of trimethyloctadecylammonium chloride (STAC) to an alkaline electrolyte solution (0.25 M $\mathrm{ZnO} / 4 \mathrm{M} \mathrm{KOH})$, is an effective way to suppress and mitigate significantly irregular shape changes in the wide current density ranges from 5 to $40 \mathrm{~mA} \mathrm{~cm}{ }^{-2} \cdot{ }^{10}$ We have inferred that the mechanism proceeds as follows: (1) dissociated cations (trimethyloctadecylammonium ions) adsorb on negatively charged protrusions responsible for shape changes which are formed in the early stages, and (2) suppression of nucleus formation (excess electrodeposition) in the regions followed by lateral growth. In considering the inhibitory effect of the steric hindrance, the alkyl chain length of the cation is one of the most important parameters. Herein, we report the influence of the alkyl chain length of the quaternary ammonium cation on $\mathrm{Zn}$ deposition morphology in an alkaline- 
based electrolyte under constant current conditions, based on the results obtained by XRD analysis, FE-SEM observation, and electrochemical impedance spectroscopy.

\section{Experimental}

$0.25 \mathrm{~mol} \mathrm{dm}^{-3}(\mathrm{M})$ Zinc oxide $(\mathrm{ZnO})$ was dissolved in an aqueous solution with $4 \mathrm{M}$ potassium hydroxide $(\mathrm{KOH})$ as a basic electrolyte solution. Tetramethylammonium chloride $\left(\mathrm{N}_{111,1}\right)$, octyltrimethylammonium chloride $\left(\mathrm{N}_{111,8}\right)$, decyltrimethylammonium chloride $\left(\mathrm{N}_{111,10}\right)$, dodecyltrimethylammonium chloride $\left(\mathrm{N}_{111,12}\right)$, tetradecyltrimethylammonium chloride $\left(\mathrm{N}_{111,14}\right)$, hexadecyltrimethylammonium chloride $\left(\mathrm{N}_{111,16}\right)$, and octadecyltrimethylammonium chloride $\left(\mathrm{N}_{111,18}\right)$ were added to the electrolyte with a concentration of $1 \mathrm{mM}$, respectively. $\mathrm{Zn}$ deposition behavior was studied by cyclic voltammetry and under constant-current charge condition using three-electrode type cells consisted of a Cu substrate $\left(1.7 \mathrm{~cm}^{2}, 18 \mu\right.$ m-thickness; Nilaco Co., Ltd.) as the working electrode, Zn plate (99.99\%; Rare Metallic) as the counter electrode, Zn wire as the reference electrode, and an electrolyte. ${ }^{10}$ Deposition morphology was observed by fieldemission scanning electron microscopy (FE-SEM, JSM-7000F; JEOL Co., Ltd.). Electrochemical impedance spectroscopy was conducted to evaluate charge transfer resistance associated with $\mathrm{Zn}$ electrodeposition using a symmetric cell composed of two equivalent Zn metal sheets (100 $\mu \mathrm{m}$, $0.76 \mathrm{~cm}^{2}$ ). The amplitude was set to $25 \mathrm{mV}_{\mathrm{p}-\mathrm{p}}$, and measurement was conducted in the frequency range of $100 \mathrm{kHz}-1 \mathrm{~Hz}$.

\section{Results and Discussion}

Regardless of the presence or absence of additives and their alkyl chain length, Zndeposition/stripping reactions successfully proceeded and the obtained deposits do not contain 
$\mathrm{ZnO}$ and $\mathrm{Zn}(\mathrm{OH})_{2}$, as far as could be detected in the XRD patterns (Figures S1, Supplemental material). In the anodic process, we confirmed two oxidation peaks related to $\mathrm{Zn}$ stripping and the $\mathrm{ZnO}$ formation. The oxide probably comes from exceeding the saturation concentration of $\left[\mathrm{Zn}(\mathrm{OH})_{4}\right]^{2-}$ at the vicinity of the electrode surface. ${ }^{5}$ Figure 1 displays FE-SEM images of $\mathrm{Zn}$ deposits obtained in $0.25 \mathrm{M} \mathrm{ZnO/4M} \mathrm{KOH}$ with $1 \mathrm{mM}$ surfactant under constant current condition of $10 \mathrm{~mA} \mathrm{~cm}{ }^{-2}$. With the short alkyl-chain length $\left(\mathrm{N}_{111,1}\right)$, no impact on deposition morphology was observed, in comparison with that in an additive free electrolyte: Zn grew as threedimensionally developed bulky deposit. $\mathrm{N}_{111,8}$ delivered mixture morphologies composed of mossy and smooth structures. On the other hand, $\mathrm{N}_{111,10}$ showed complete smooth deposition morphology. As an overall trend, surface structures appear to become smoother as alkyl chain length increases. In the case of alkyl chain lengths with $\mathrm{C}_{10}$ or more, mossy and dendritic growth are not confirmed even with microscopic observation, which indicates that the bulkiness of the quaternary ammonium cation varies with alkyl chain length and has significant influence on deposition morphology. In the electrolyte with $1 \mathrm{mM} \mathrm{N} \mathrm{N}_{111,8}$, the smooth crystallographic face was larger than other systems and size of deposited Zn particle became smaller in the electrolyte with 1 mM N 111,18 (Figures S2, Supplemental material). Potential behaviors during Zn deposition under the constant current density are shown in Figure 2a. In an additive free electrolyte, Zn nucleus

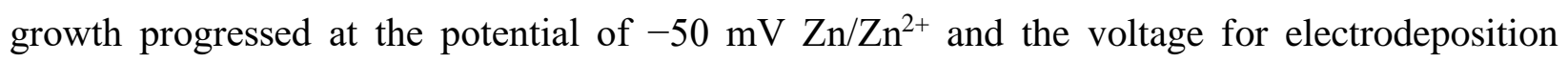
eventually resulted in $-40 \mathrm{mV}$, which is due to the formation of mossy structure with large surface areas. The potential in an electrolyte with $1 \mathrm{mM} \mathrm{N} \mathrm{N}_{111,8}$ was $-64 \mathrm{mV}$ when capacity reached $10 \mathrm{~mA}$ $\mathrm{h} \mathrm{cm}^{-2}$. The potentials remained almost the same value of $-90 \mathrm{mV}$ in the case of alkyl chain lengths with more than $\mathrm{C}_{10}\left(\mathrm{~N}_{111,10}\right)$. The smaller grain size of electrodeposited $\mathrm{Zn}$ becomes, the larger reactive site expands and the smaller overpotential diminishes. Although it is difficult to exactly 
distinguish grain sizes, the grain size of electrodeposited $\mathrm{Zn}$ in an electrolyte with $1 \mathrm{mM} \mathrm{N}_{111,18}$ seems to be the smallest. This should be why the overpotentials do not depend on the alkyl chain length. Positively charged cations formed by the ionization of the surfactant are attracted by a negatively charged electrode by not only electrostatic interaction but also adsorption effect. ${ }^{11}$ The charge density of the monovalent cations become weaker as chain length increase due to the electron donation effect derived from the alkyl group. ${ }^{12}$ Considering the morphology control of $\mathrm{Zn}$ deposition during electrochemical growth, the suppression of shape change should originate from steric hindrance rather than charge density upon electrostatic interaction. For exploring the steric hindrance effect on crystalline morphology, we investigated the crystal orientation of the $\mathrm{Zn}$ deposits by relative texture coefficient $\mathrm{RTC}_{(h k l)}$ according to the following equation ${ }^{13,14}$ (Figure 2b):

$$
\mathrm{RTC}_{(h k l)}=\frac{I_{h k l} / I_{h k l}^{o}}{\sum_{1}^{5} I_{h k l} / I_{h k l}^{o}} \times 100 \%
$$

where $I_{\mathrm{hkl}}$ and $I^{\mathrm{o}} \mathrm{hkl}$ denote the diffraction intensities of the $(h k l)$ lines for the deposited $\mathrm{Zn}$ and the corresponding intensities of the commercially available $\mathrm{Zn}$ powder sample which is randomly orientated, respectively. ${ }^{8}$ Since we focused on the five dominant peaks of Zn (002), (100), (101), (102), and (110) planes, a preferred orientation through an axis [hkl] is indicated by values of RTC $\geq 20 \%$, and the preferred orientation is absolute when RTC approaches the value of $100 \%$. Zn deposits show random orientation in an additive free electrolyte, and (102) a plane gradually developed in the range of $\mathrm{N}_{111,8}$ to $\mathrm{N}_{111,12}$. At $\mathrm{N}_{111,14}$ or longer, the orientation to [110] became pronounced and RTC for the orientation was approximately $70 \%$. Although quaternary cations adsorb on a specific crystal plane to promote electrochemical Zn growth toward a certain direction, 
it is still unclear and we are now trying to verifying the growth mechanism on each lattice plane through the use of a single-crystal substrate. The important point to be emphasized is that $\mathrm{Zn}$ deposition morphology accompanied by crystal orientation can be controlled by adjusting alkyl chain length of quaternary ammonium cation.

Figure 3 represents Nyquist plots of symmetric cells with two identical Zn metal sheets ( $\varphi$ $13 \mathrm{~mm}$ ) in various electrolyte solutions. One semicircle assigned to charge transfer involved in Zn-deposition was observed. The charge transfer resistance in an additive free electrolyte was 0.74 $\Omega \mathrm{cm}^{2}$, whereas the resistance in an electrolyte with $\mathrm{N}_{111,10}$ in which mossy and dendritic structures were completely suppressed was $3.91 \Omega \mathrm{cm}^{2}$. The results where the resistance increased as alkyl chain length increased indicates that ammonium cations adsorb on an electrode surface to suppress excess electrodeposition reactions on protrusions which are formed at earlier stages and are the cause of the shape change. We are investigating the influence of the ammonium cations on Zn-stripping reactions.

\section{Summary}

The effect of alkyl chain length in quaternary ammonium cation on $\mathrm{Zn}$ deposition morphology was studied by FE-SEM, XRD, and EIS measurements. It was found that mossy and dendritic structures were mitigated in an electrolyte with $\mathrm{N}_{111,8}$. In the case of alkyl chain length with $\mathrm{C}_{10}$ or more, charge transfer related to $\mathrm{Zn}$-deposition was increased compared with that in an additive free electrolyte and therefore resulted in smooth morphology by the suppression of excess electrodeposition on protrusions which are responsible for mossy structures.

\section{Acknowledgments}


This work was supported by Early-Career Scientists (18K14317) from JSPS and research grants from the Iketani Science and Technology Foundation (0301043-A) and from the Yashima Environment Technology Foundation. M. Shimizu gratefully acknowledges T. Elliot for the advice. 


\section{References}

1. F. Wang, O. Borodin, T. Gao, X. Fan, W. Sun, F. Han, A. Faraone, J. A. Dura, K. Xu and C. Wang, Nat. Mater., 17, 543 (2018).

2. Y. Li and H. Dai, Chem. Soc. Rev., 43, 5257 (2014).

3. T. Otani, M. Nagata, Y. Fukunaka and T. Homma, Electrochim. Acta, 206, 366 (2016).

4. D. Stock, S. Dongmo, F. Walther, J. Sann, J. Janek and D. Schroder, ACS Appl. Mater. Interfaces, 10, 8640 (2018).

5. A. Nakata, H. Arai, T. Yamane, T. Hirai and Z. Ogumi, J. Electrochem. Soc., 163, A50 (2016).

6. A. Gomes and M. I. da Silva Pereira, Electrochimica Acta, 52, 863 (2006).

7. K. Miyazaki, A. Nakata, Y.-S. Lee, T. Fukutsuka and T. Abe, J. Appl. Electrochem., 46, 1067 (2016).

8. X. Wei, D. Desai, G. G. Yadav, D. E. Turney, A. Couzis and S. Banerjee, Electrochim. Acta, 212, 603 (2016).

9. J. F. Parker, E. S. Nelson, M. D. Wattendorf, C. N. Chervin, J. W. Long and D. R. Rolison, ACS Appl. Mater. Interfaces, 6, 19471 (2014).

10. M. Shimizu, K. Hirahara and S. Arai, Phys. Chem. Chem. Phys., 21, 7045 (2019).

11. Z. Liu, T. Cui, G. Pulletikurthi, A. Lahiri, T. Carstens, M. Olschewski and F. Endres, Angew. Chem., 55, 2889 (2016).

12. Q. Yang, Z. Zhang, X. G. Sun, Y. S. Hu, H. Xing and S. Dai, Chem. Soc. Rev., 47, 2020 (2018).

13. M. Shimizu, R. Yatsuzuka, M. Horita, T. Yamamoto and S. Arai, J. Phys. Chem. C, 121, 27285 (2017).

14. E. A. Pavlatou, M. Raptakis and N. Spyrellis, Surf. Coat. Technol., 201, 4571 (2007). 


\section{Figure captions}

Figure 1. Dependence of alkyl chain length of quaternary ammonium ion on $\mathrm{Zn}$ deposition morphology in alkaline-based electrolyte ( $0.25 \mathrm{M} \mathrm{ZnO/4M} \mathrm{KOH})$ : surface and cross-sectional FESEM images of Zn deposits obtained by respective electrolytes. Charge capacity for Zn deposition and current density are $10 \mathrm{~mA} \mathrm{~h} \mathrm{~cm}{ }^{-2}$ and $10 \mathrm{~mA} \mathrm{~cm}^{-2}$, respectively.

Figure 2. (a) Zn-deposition behavior under constant current density of $10 \mathrm{~mA} \mathrm{~cm}^{-2}$ in electrolyte solutions of $0.25 \mathrm{M} \mathrm{ZnO} / 4 \mathrm{M} \mathrm{KOH}$ with $1 \mathrm{mM}$ surfactant. (b) Change in relative texture coefficient for Zn (110), (002), (110), (101), and (102) diffraction peaks.

Figure 3. Nyquist plots of symmetric Zn|Zn metal sheets cells in $0.25 \mathrm{M} \mathrm{ZnO/4} \mathrm{M} \mathrm{KOH}$ with 1 $\mathrm{mM}$ additive at $303 \mathrm{~K}$. Inset: the equivalent circuit for impedance analysis. The area of both $\mathrm{Zn}$ electrode is $1.33 \mathrm{~cm}^{2}$. Plots at a frequency of $673 \mathrm{~Hz}$ are shown in white. 


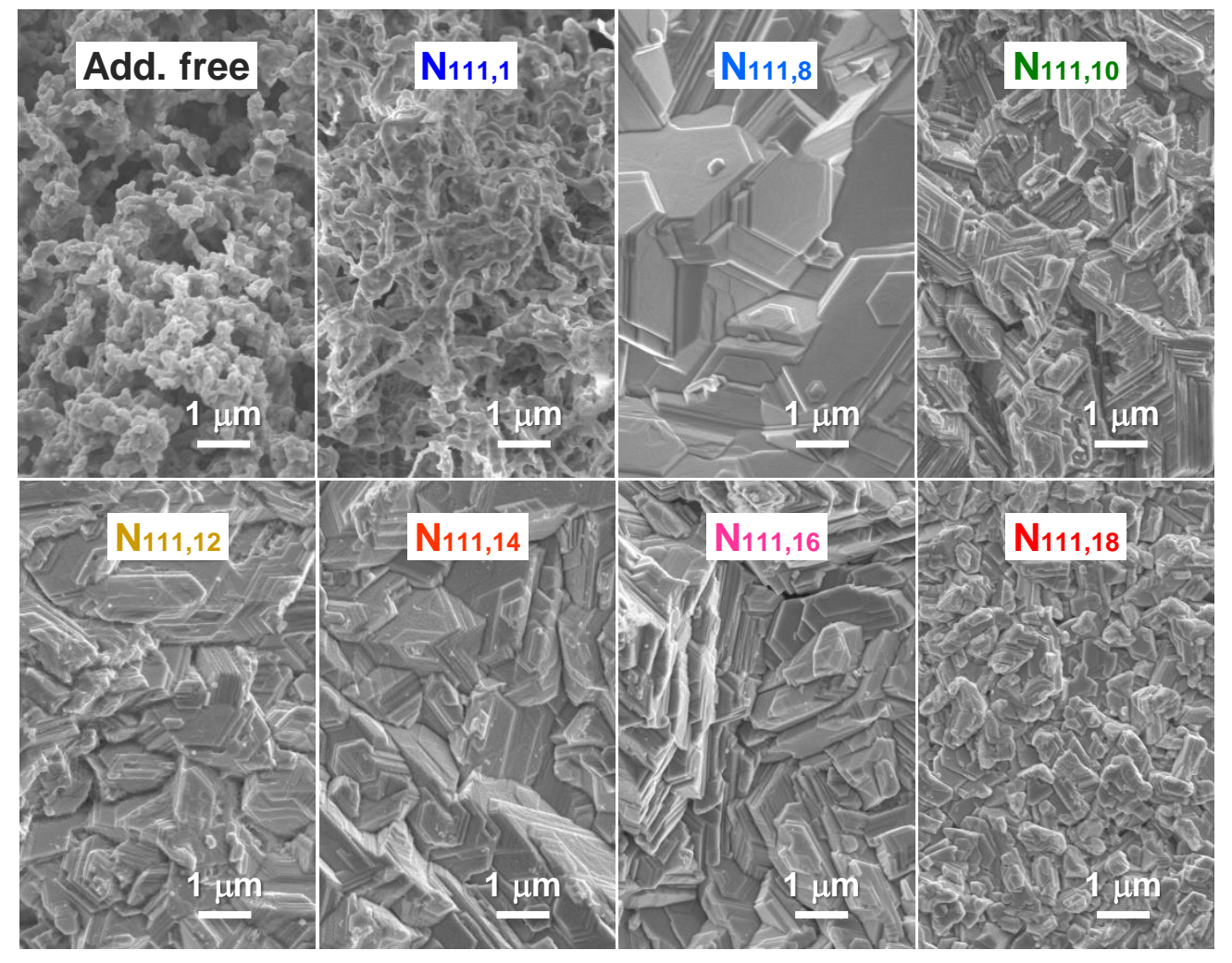

Figure 1. Dependence of alkyl chain length of quaternary ammonium ion on $\mathrm{Zn}$ deposition morphology in alkaline-based electrolyte $(0.25 \mathrm{M} \mathrm{ZnO} / 4 \mathrm{M} \mathrm{KOH})$ : surface and cross-sectional FE-SEM images of Zn deposits obtained by respective electrolytes. Charge capacity for $\mathrm{Zn}$ deposition and current density are $10 \mathrm{~mA} \mathrm{~h}$ $\mathrm{cm}^{-2}$ and $10 \mathrm{~mA} \mathrm{~cm}{ }^{-2}$, respectively. 


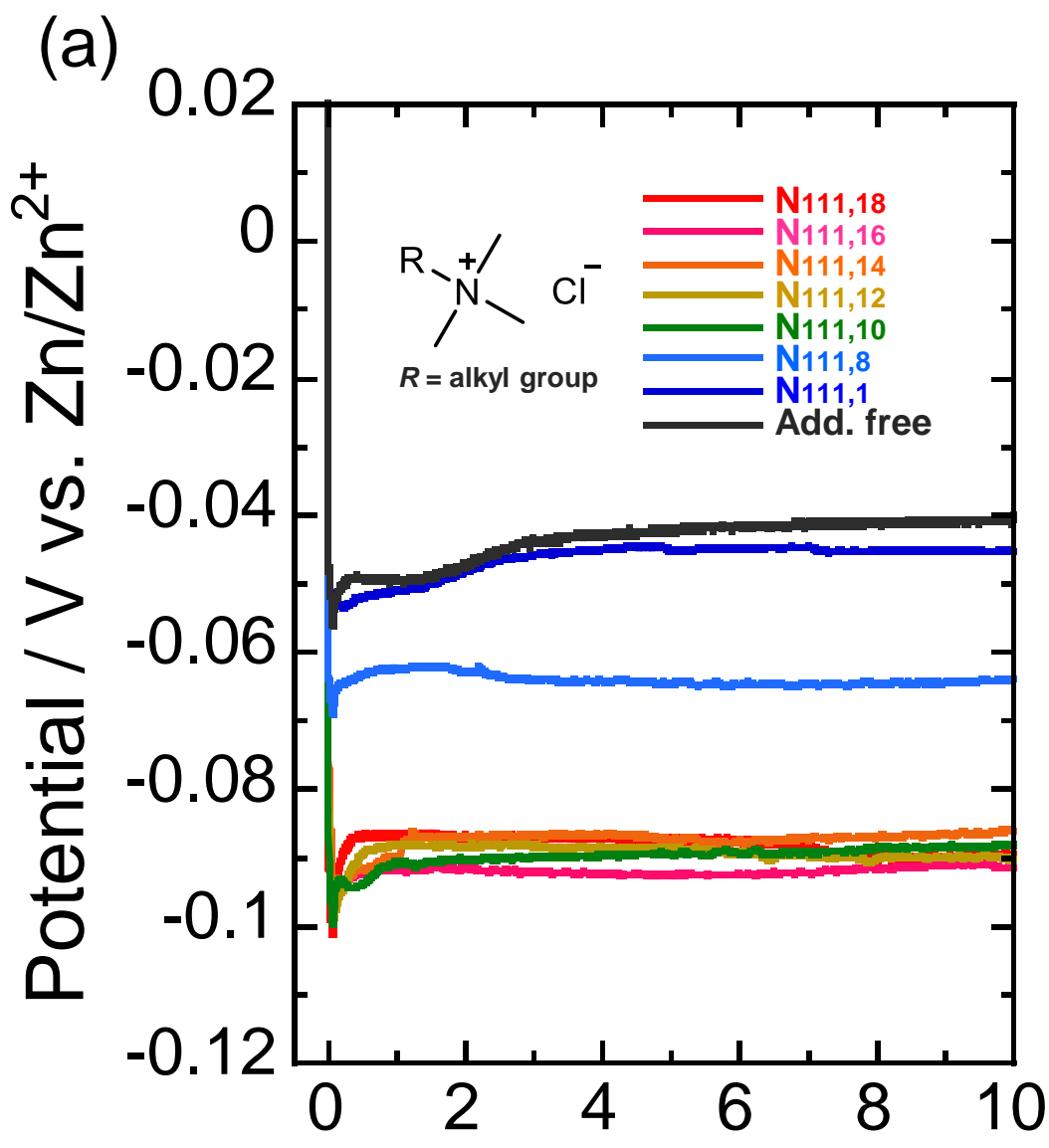

Capacity / $\mathrm{mA} \mathrm{h} \mathrm{cm}^{-2}$

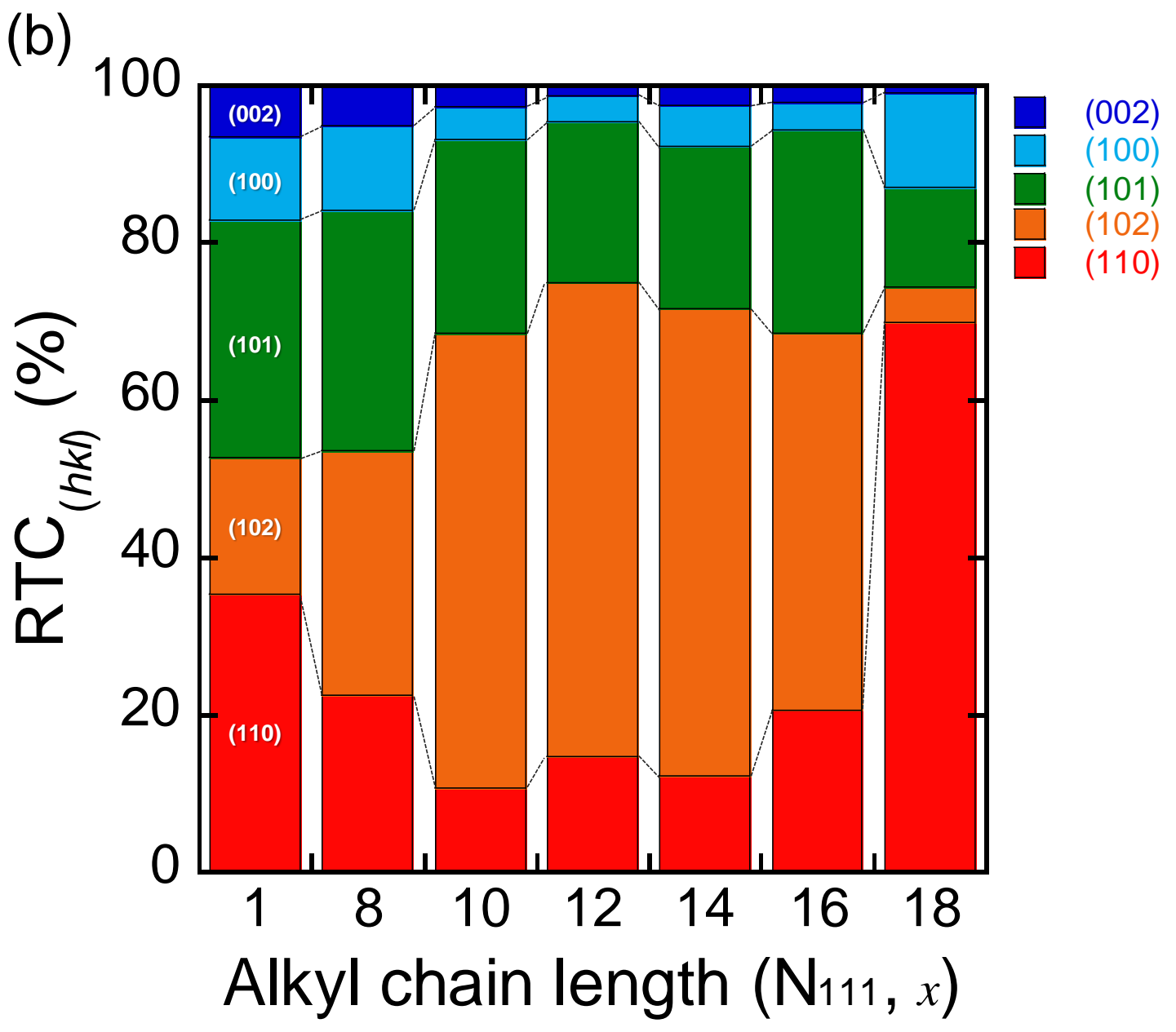

Figure 2. (a) Zn-deposition behavior under constant current density of $10 \mathrm{~mA}$ $\mathrm{cm}^{-2}$ in electrolyte solutions of $0.25 \mathrm{M} \mathrm{ZnO} / 4 \mathrm{M} \mathrm{KOH}$ with $1 \mathrm{mM}$ surfactant. Inset: photographs of $\mathrm{Zn}$ deposits. (b) Change in relative texture coefficient for $\mathrm{Zn}$ (110), (002), (110), (101), and (102) diffraction peaks. 


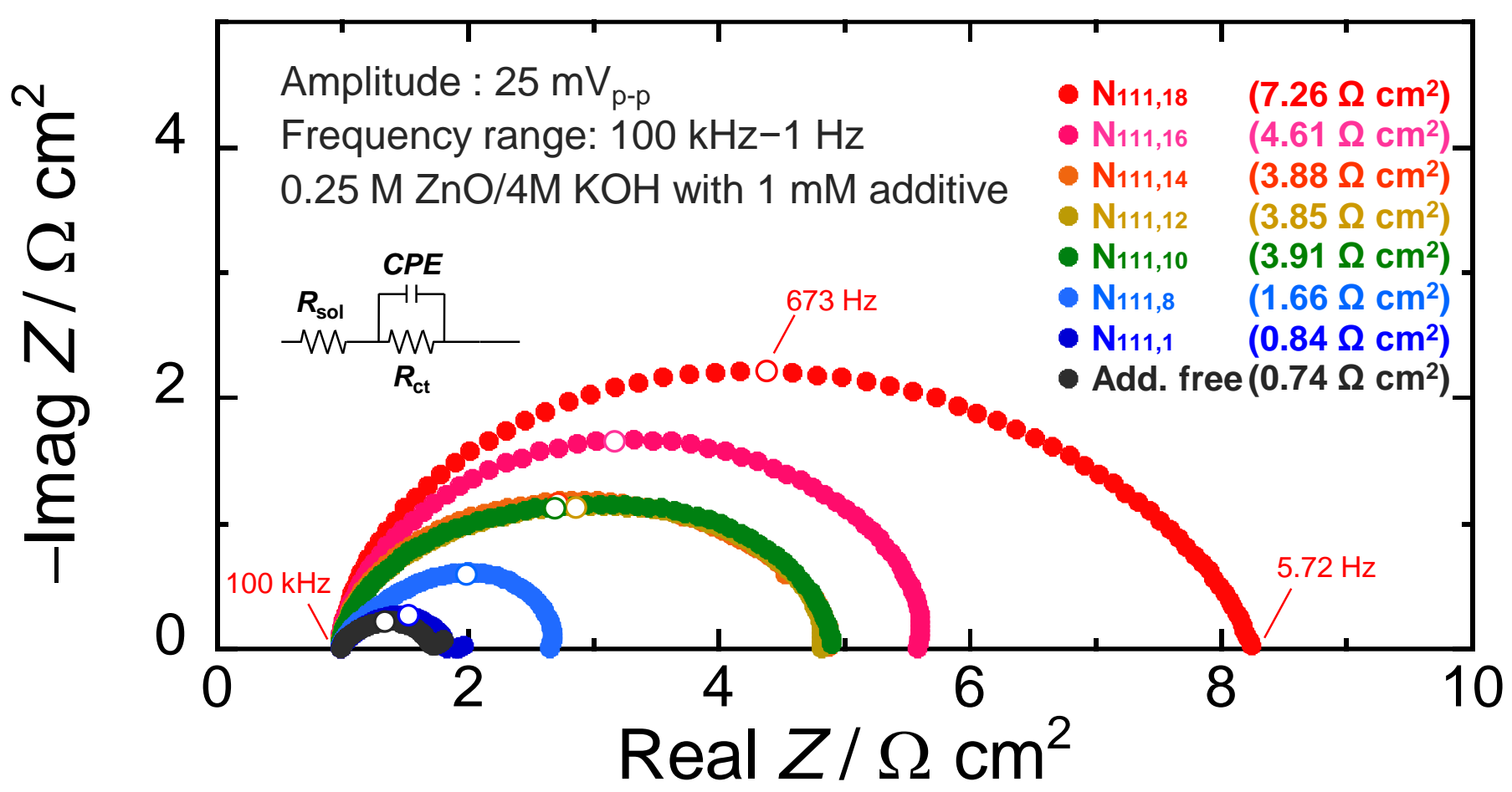

Figure 3. Nyquist plots of symmetric $\mathrm{Zn} \mid \mathrm{Zn}$ metal sheets cells in $0.25 \mathrm{M} \mathrm{ZnO} / 4$ $\mathrm{M} \mathrm{KOH}$ with $1 \mathrm{mM}$ additive at $303 \mathrm{~K}$. Inset: the equivalent circuit for impedance analysis. The area of both $\mathrm{Zn}$ electrode is $1.33 \mathrm{~cm}^{2}$. Plots at a frequency of $673 \mathrm{~Hz}$ are shown in white. 


\section{Supporting Information}

\section{Alkyl-Chain-Length Dependence of Quaternary Ammonium Cation on Zn Deposition Morphology in Alkaline-based Electrolytes}

${ }^{\dagger}$ Department of Materials Chemistry, Faculty of Engineering, Shinshu University

${ }^{\ddagger}$ Institute of Carbon Science and Technology, Faculty of Engineering, Shinshu University

4-17-1 Wakasato, Nagano 380-8553, Japan

Masahiro Shimizu ${ }^{*},+, \neq$, Koichi Hirahara ${ }^{\dagger}$,

Yuki Ishida, ${ }^{\dagger}$ Susumu Arai ${ }^{*},+\neq$

Dr. Masahiro Shimizu

E-mail: shimizu@shinshu-u.ac.jp

Tel: +81-26-269-5627; Fax: +81-26-269-5627 


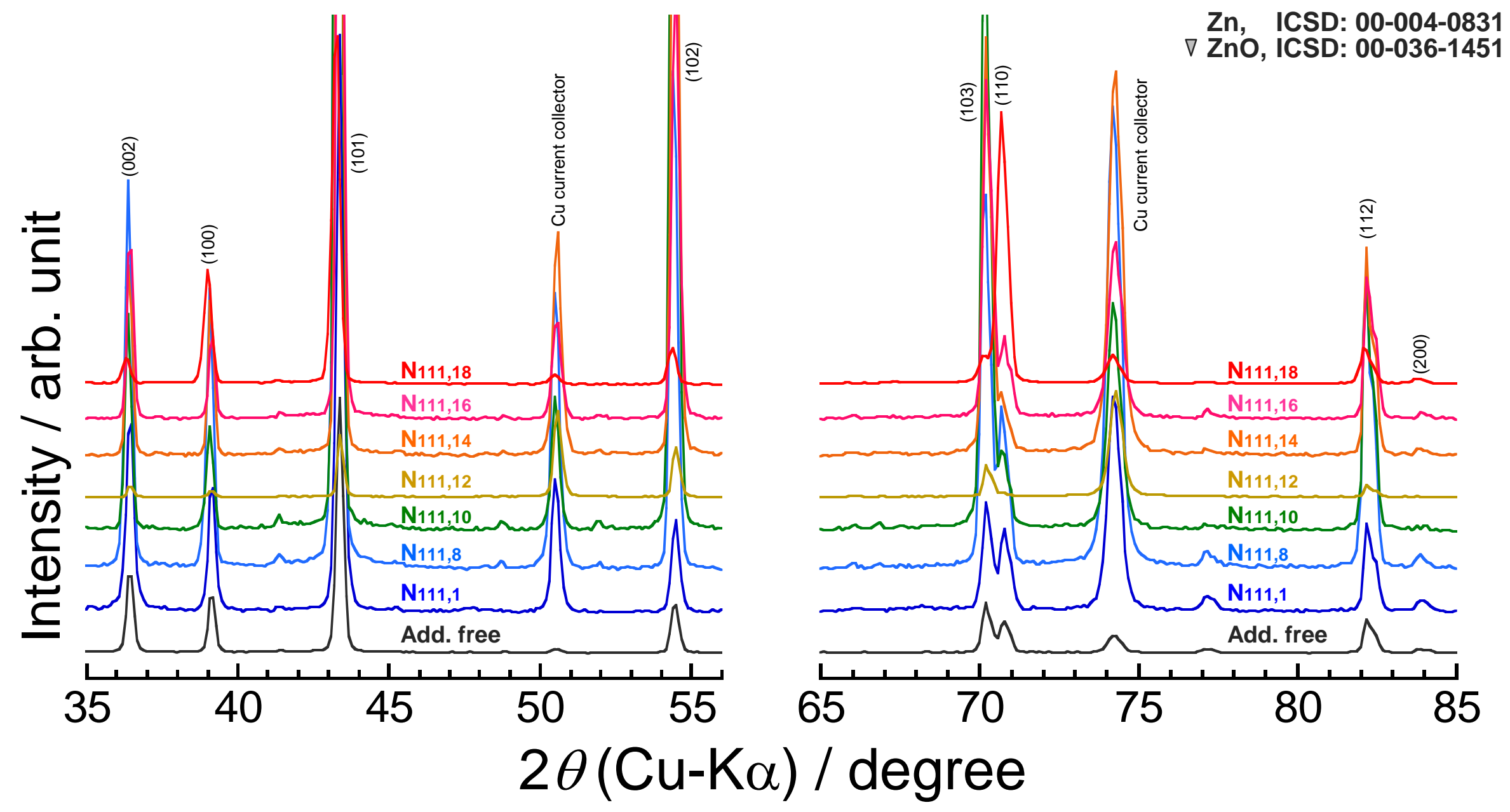

Figure S1. XRD patterns of deposits obtained from electrolyte solutions of 0.25 $\mathrm{M} \mathrm{ZnO/4M} \mathrm{KOH}$ with $1 \mathrm{mM}$ additive. In the measurements, $\mathrm{Zn}$ deposition was conducted at a current density of $10 \mathrm{~mA} \mathrm{~cm}^{-2}$. 


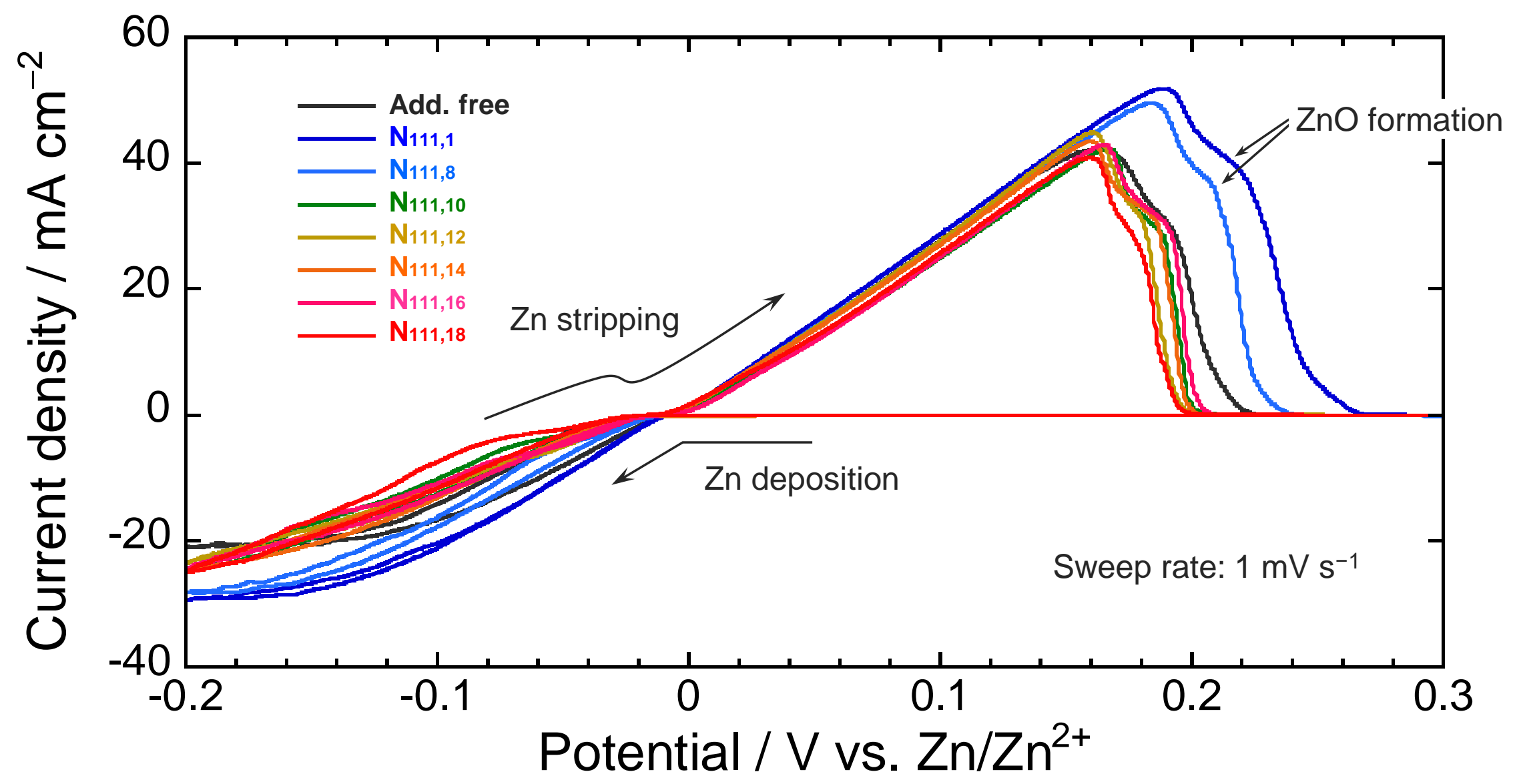

Figure S2. Cyclic voltammograms corresponding to Zn-deposition/stripping in aqueous solutions of $0.25 \mathrm{M}+4 \mathrm{M} \mathrm{KOH}$ without and with surfactant $\left(\mathrm{N}_{111, x}\right)$. The area of current collector was $1.7 \mathrm{~cm}^{2}$. As alkyl chain length becomes long, potentials of $\mathrm{Zn}$ deposition and stripping tend to shift to negative side and positive side, respectively. 


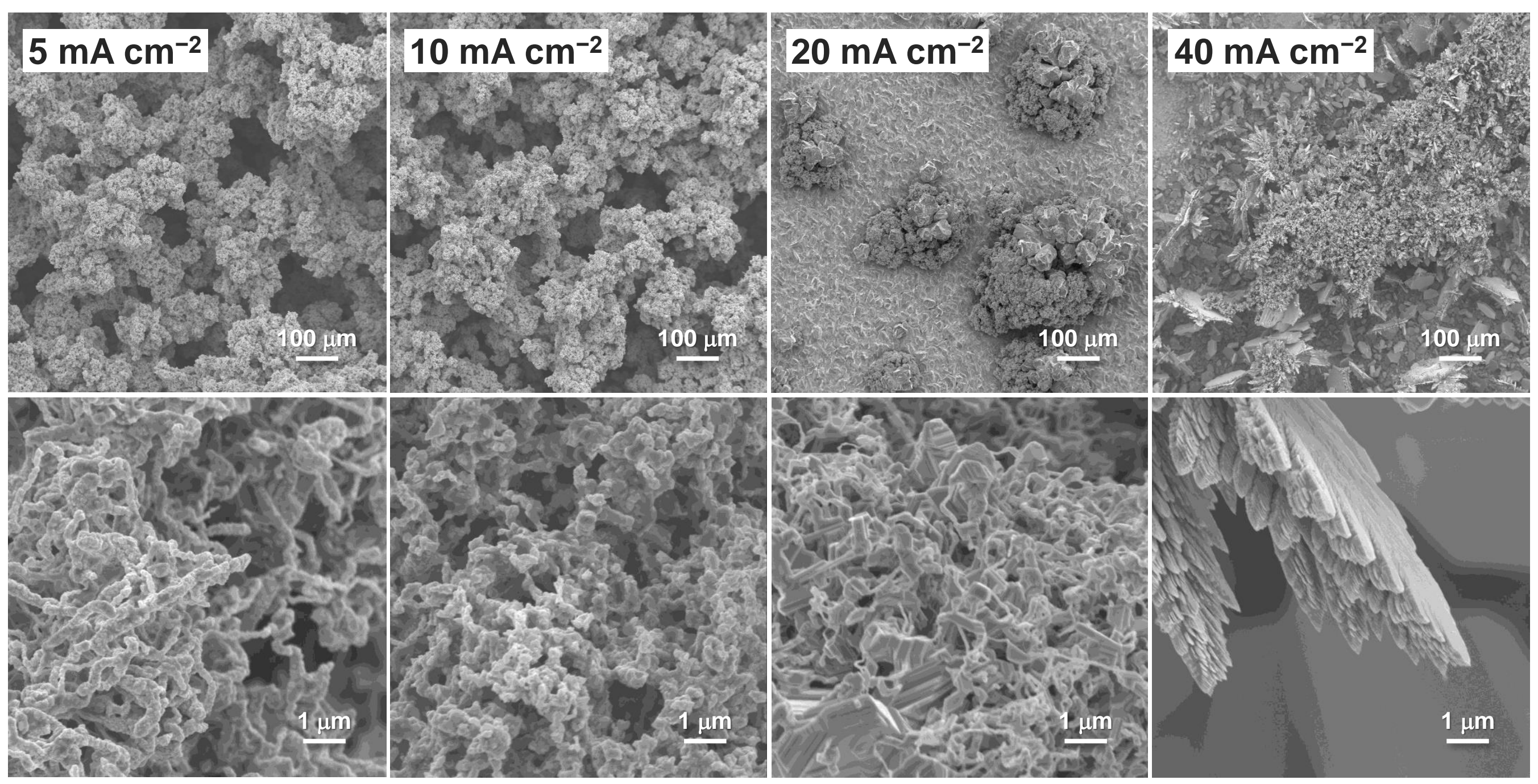

Figure S3. FE-SEM images of electrochemically grown $\mathrm{Zn}$ on a $\mathrm{Cu}$ substrate in a surfactant-free aqueous solution of $0.25 \mathrm{M} \mathrm{ZnO/4} \mathrm{M} \mathrm{KOH}$ under various current densities. Charge capacity was $10 \mathrm{~mA} \mathrm{~h} \mathrm{~cm}^{-2}$. 


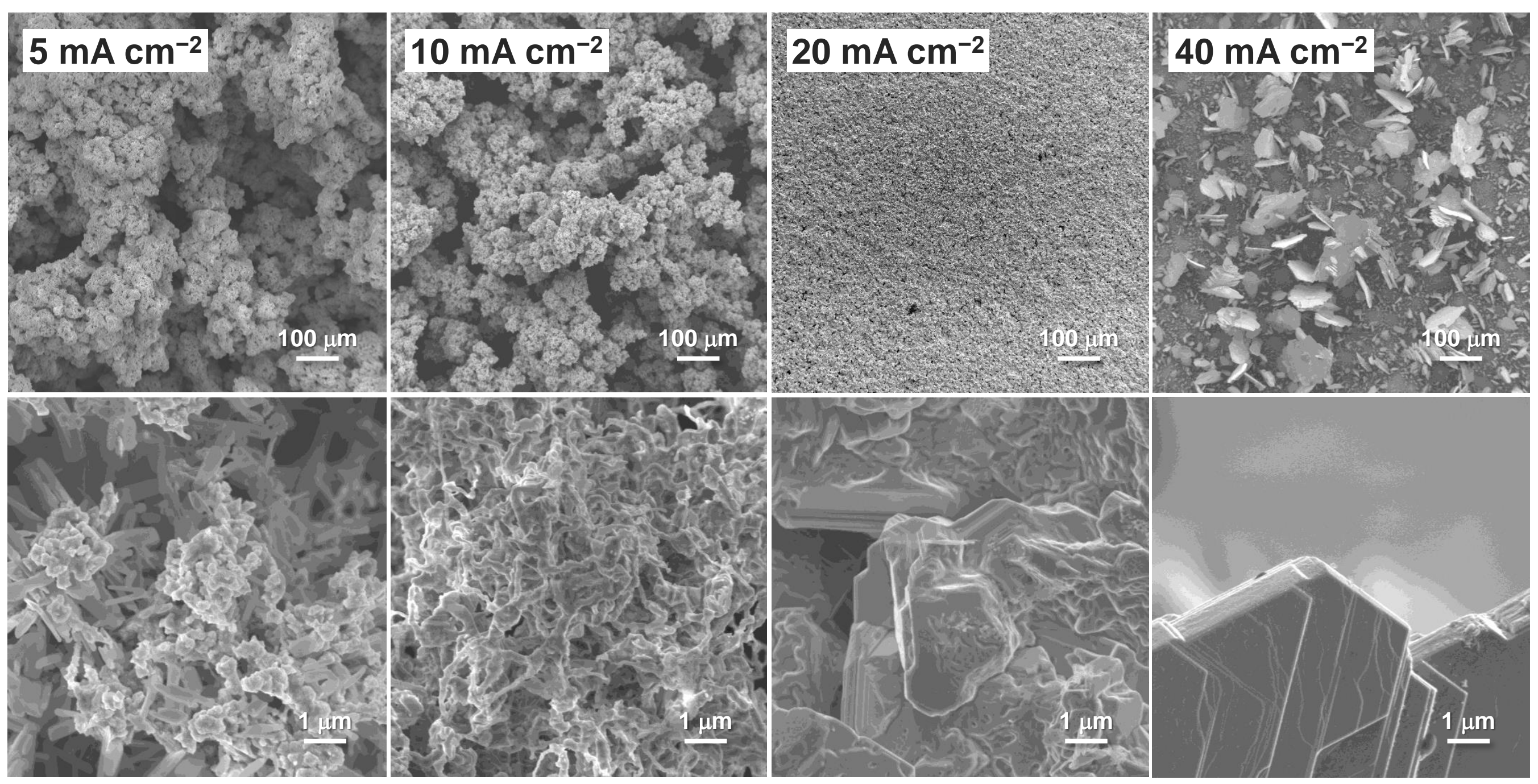

Figure S4. FE-SEM images of electrochemically grown $\mathrm{Zn}$ on a $\mathrm{Cu}$ substrate in an aqueous solution of $0.25 \mathrm{M} \mathrm{ZnO/4} \mathrm{M} \mathrm{KOH}$ with $1 \mathrm{mM} \mathbf{N}_{111,1}$ under various current densities. Charge capacity was $10 \mathrm{~mA} \mathrm{~h} \mathrm{~cm}^{-2}$. 


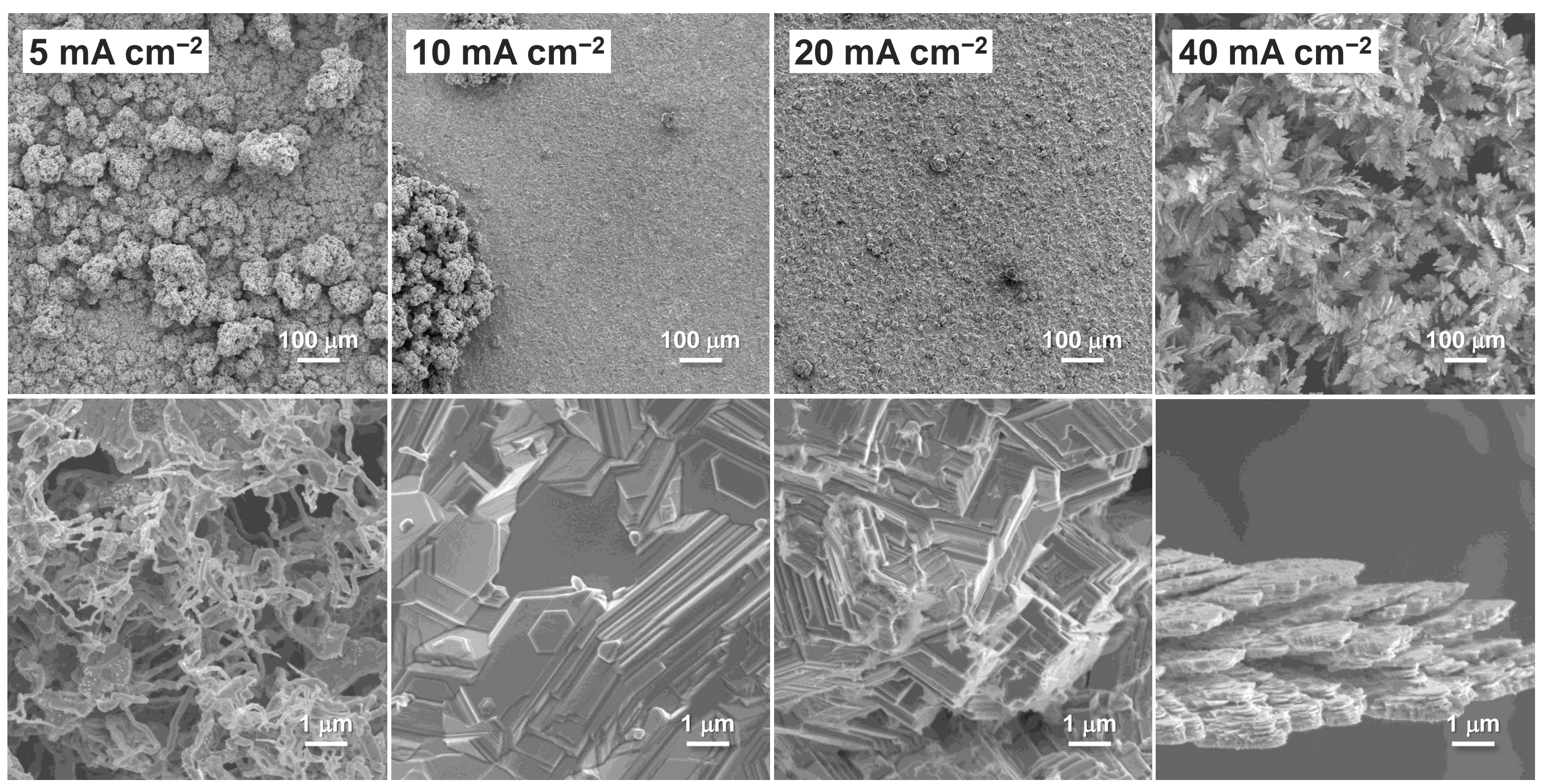

Figure S5. FE-SEM images of electrochemically grown $\mathrm{Zn}$ on a $\mathrm{Cu}$ substrate in an aqueous solution of $0.25 \mathrm{M} \mathrm{ZnO/4} \mathrm{M} \mathrm{KOH}$ with $1 \mathrm{mM} \mathbf{N}_{111,8}$ under various current densities. Charge capacity was $10 \mathrm{~mA} \mathrm{~h} \mathrm{~cm}^{-2}$. 


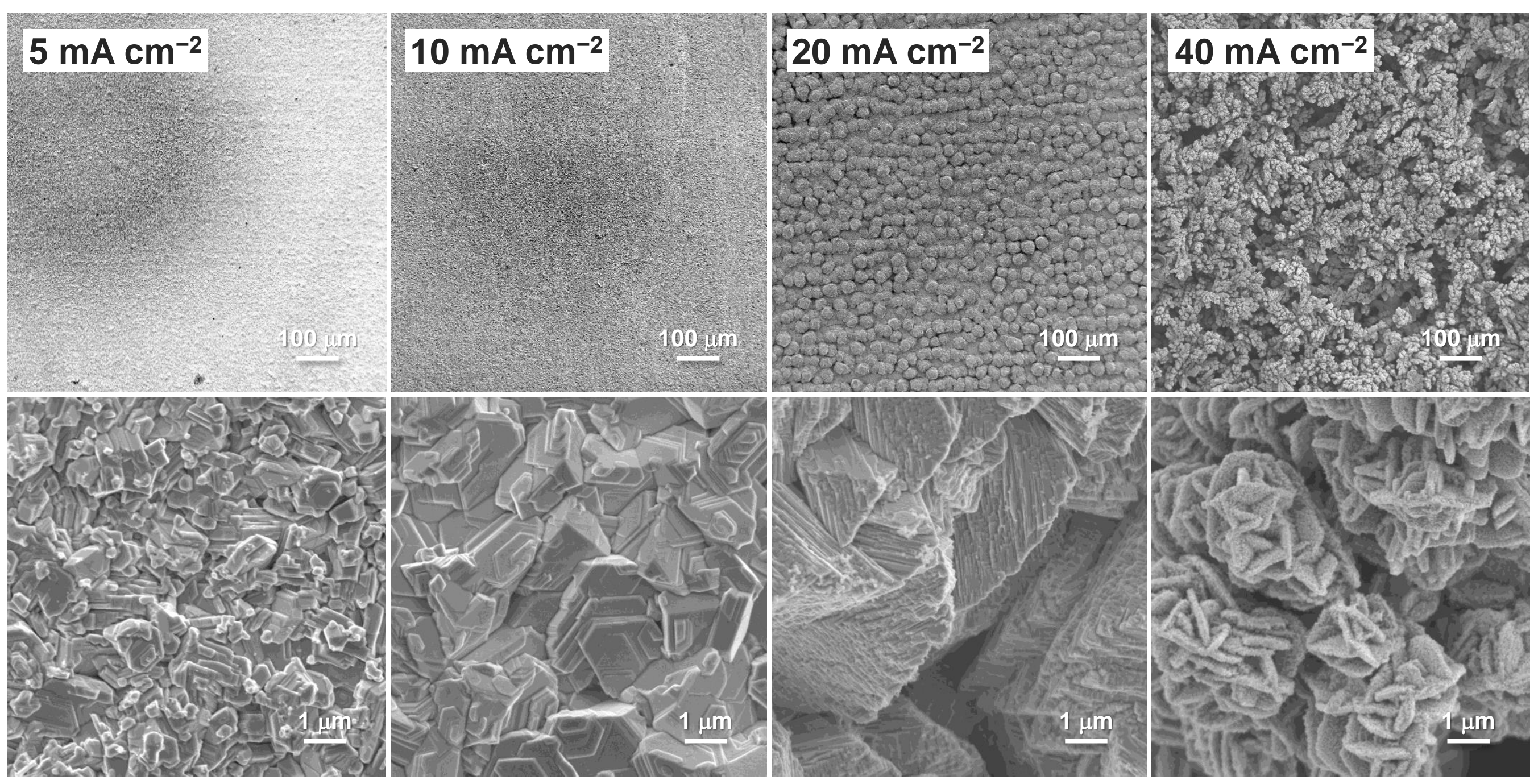

Figure S6. FE-SEM images of electrochemically grown $\mathrm{Zn}$ on a $\mathrm{Cu}$ substrate in an aqueous solution of $0.25 \mathrm{M} \mathrm{ZnO/4} \mathrm{M} \mathrm{KOH}$ with $1 \mathrm{mM} \mathrm{N}_{111,10}$ under various current densities. Charge capacity was $10 \mathrm{~mA} \mathrm{~h} \mathrm{~cm}^{-2}$. 


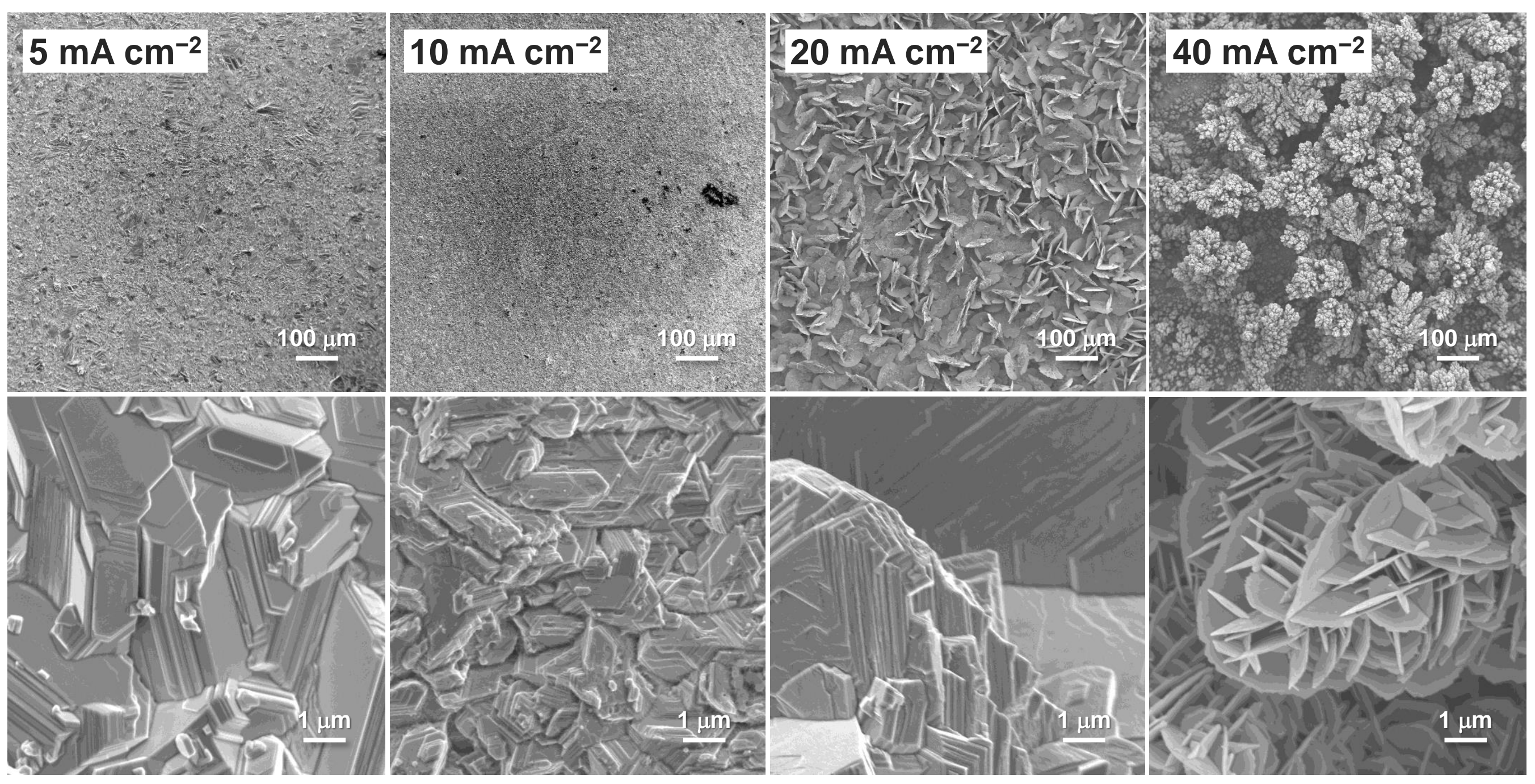

Figure S7. FE-SEM images of electrochemically grown $\mathrm{Zn}$ on a $\mathrm{Cu}$ substrate in an aqueous solution of $0.25 \mathrm{M} \mathrm{ZnO/4} \mathrm{M} \mathrm{KOH}$ with $1 \mathrm{mM} \mathrm{N}_{111,12}$ under various current densities. Charge capacity was $10 \mathrm{~mA} \mathrm{~h} \mathrm{~cm}^{-2}$. 


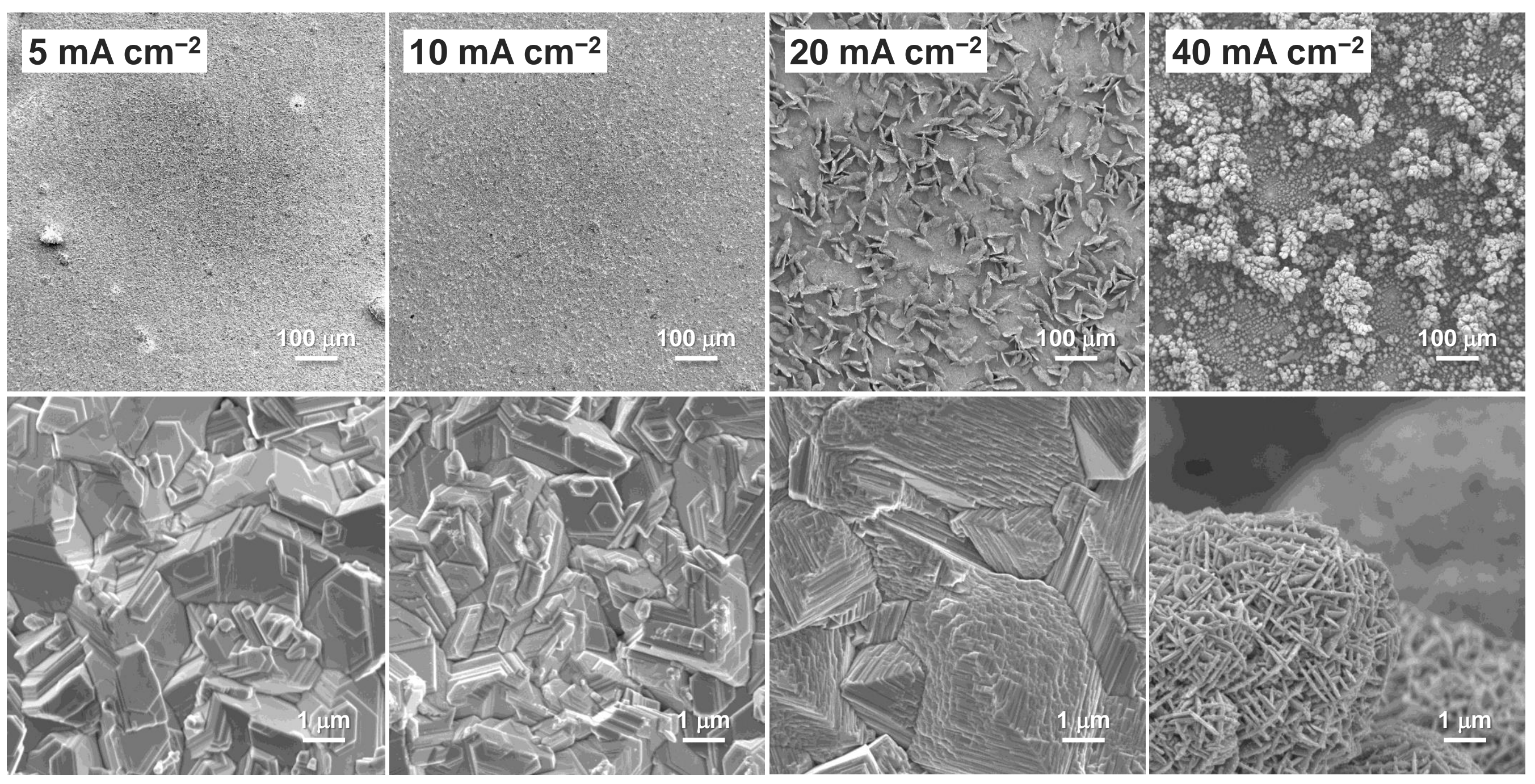

Figure S8. FE-SEM images of electrochemically grown $\mathrm{Zn}$ on a $\mathrm{Cu}$ substrate in an aqueous solution of $0.25 \mathrm{M} \mathrm{ZnO} / 4 \mathrm{M} \mathrm{KOH}$ with $1 \mathrm{mM} \mathrm{N} \mathrm{N}_{111,14}$ under various current densities. Charge capacity was $10 \mathrm{~mA} \mathrm{~h} \mathrm{~cm}^{-2}$. 


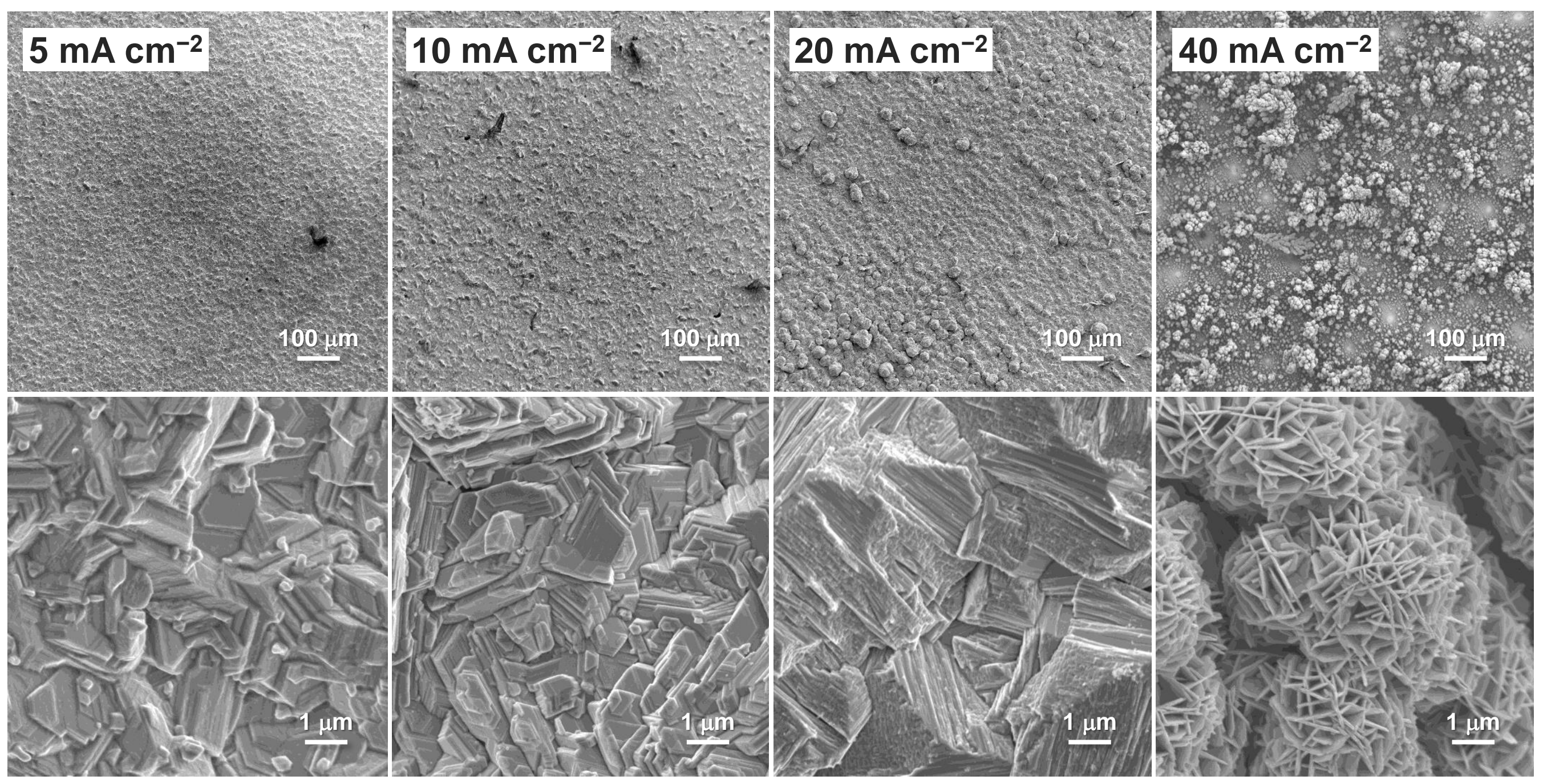

Figure S9. FE-SEM images of electrochemically grown $\mathrm{Zn}$ on a $\mathrm{Cu}$ substrate in an aqueous solution of $0.25 \mathrm{M} \mathrm{ZnO/4} \mathrm{M} \mathrm{KOH}$ with $1 \mathrm{mM} \mathrm{N}_{111,16}$ under various current densities. Charge capacity was $10 \mathrm{~mA} \mathrm{~h} \mathrm{~cm}^{-2}$. 


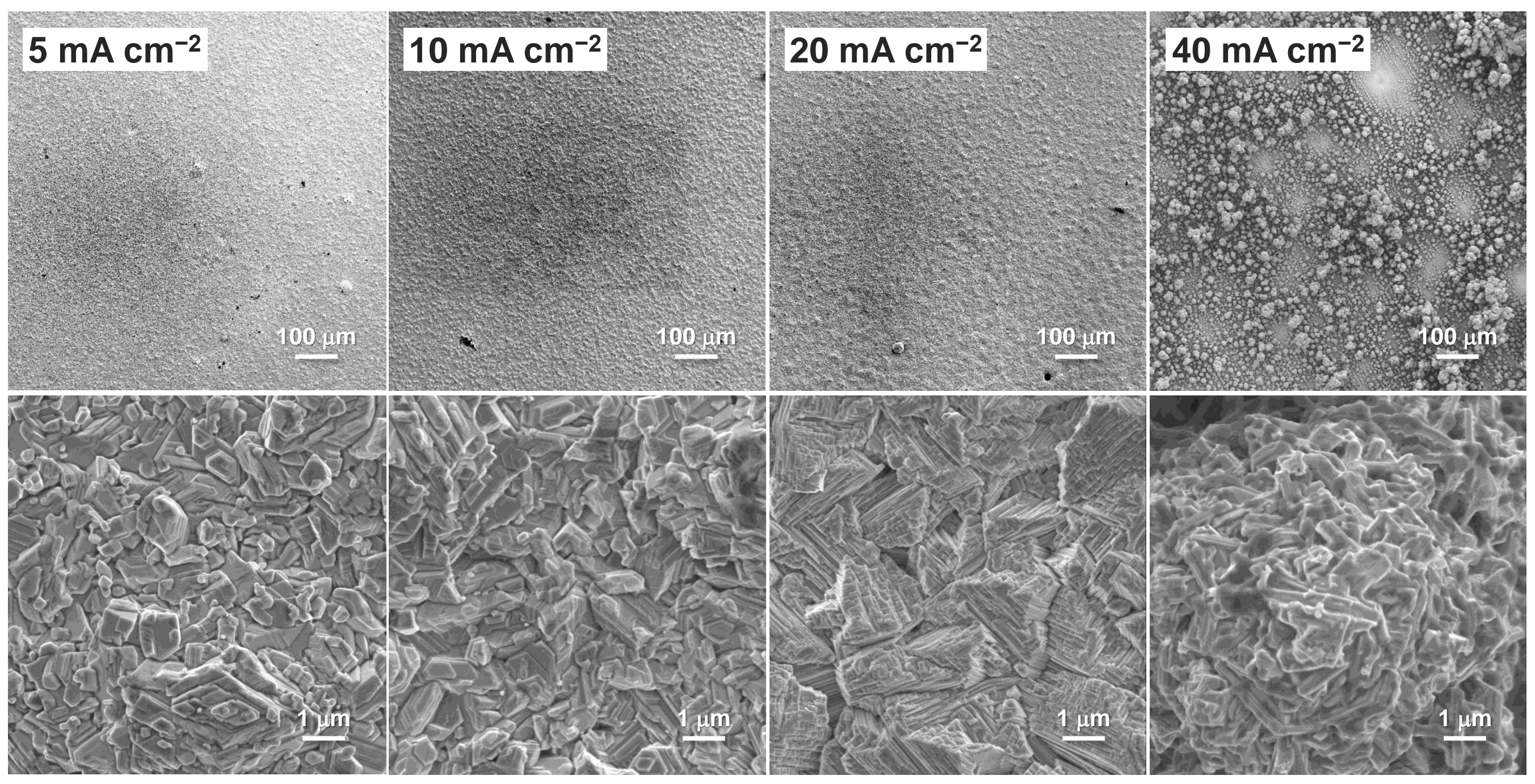

Figure S10. FE-SEM images of electrochemically grown $\mathrm{Zn}$ on a $\mathrm{Cu}$ substrate in an aqueous solution of $0.25 \mathrm{M} \mathrm{ZnO/4} \mathrm{M} \mathrm{KOH}$ with $1 \mathrm{mM} \mathrm{N}_{111,18}$ under various current densities. Charge capacity was $10 \mathrm{~mA} \mathrm{~h} \mathrm{~cm}^{-2}$. 


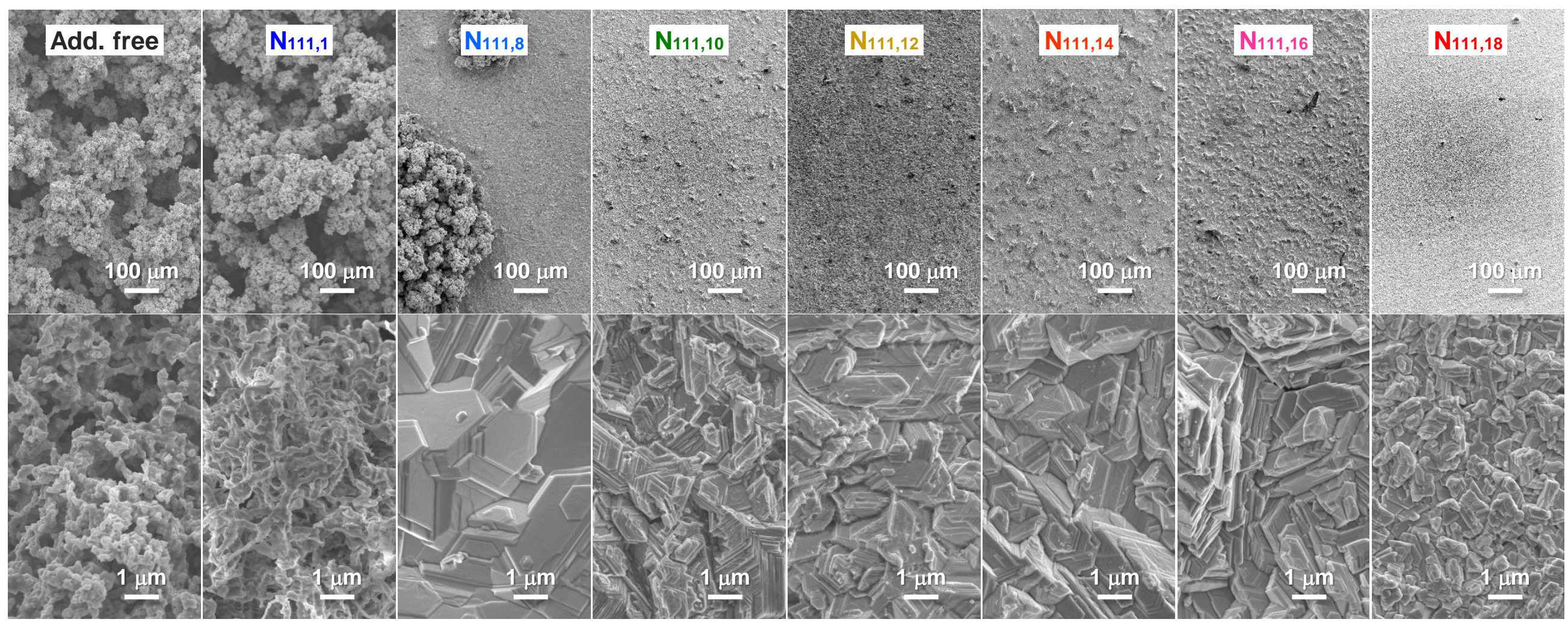

Figure 1. Dependence of alkyl chain length of quaternary ammonium ion on $\mathrm{Zn}$ deposition morphology in alkaline-based electrolyte $(0.25 \mathrm{M} \mathrm{ZnO} / 4 \mathrm{M} \mathrm{KOH})$ : surface and cross-sectional FE-SEM images of $\mathrm{Zn}$ deposits obtained by respective electrolytes. Charge capacity for $\mathrm{Zn}$ deposition and current density are $10 \mathrm{~mA} \mathrm{~h}$ $\mathrm{cm}^{-2}$ and $10 \mathrm{~mA} \mathrm{~cm}{ }^{-2}$, respectively. 
Table S1. Summary of crystallite size in several lattice plane calculated by XRD patterns of $\mathrm{Zn}$ deposits obtained from electrolyte solutions of $0.25 \mathrm{ZnO} / 4 \mathrm{M} \mathrm{KOH}$ without and with $1 \mathrm{mM}$ additive. Charge capacity and current density are $10 \mathrm{~mA} \mathrm{~h}$ $\mathrm{cm}^{-2}$, and $10 \mathrm{~mA} \mathrm{~cm}^{-2}$, respectively.

\begin{tabular}{ccccccccc}
\hline \multirow{2}{*}{$\begin{array}{c}\text { Lattice } \\
\text { plane }\end{array}$} & \multicolumn{7}{c}{ Crystallite size / nm } \\
\cline { 2 - 9 } & Add. free & $N_{111,1}$ & $N_{111,8}$ & $N_{111,10}$ & $N_{111,12}$ & $N_{111,14}$ & $N_{111,16}$ & $N_{111,18}$ \\
\hline$(002)$ & 35 & 38 & 35 & 36 & 49 & 38 & 41 & 32 \\
$(100)$ & 37 & 34 & 34 & 49 & 37 & 34 & 42 & 32 \\
$(101)$ & 39 & 35 & 35 & 42 & 38 & 41 & 43 & 34 \\
$(102)$ & 38 & 37 & 51 & 52 & 36 & 41 & 43 & 34 \\
$(110)$ & 41 & 39 & 45 & 47 & 50 & 45 & 53 & 38 \\
\hline
\end{tabular}




\section{Graphical abstract}

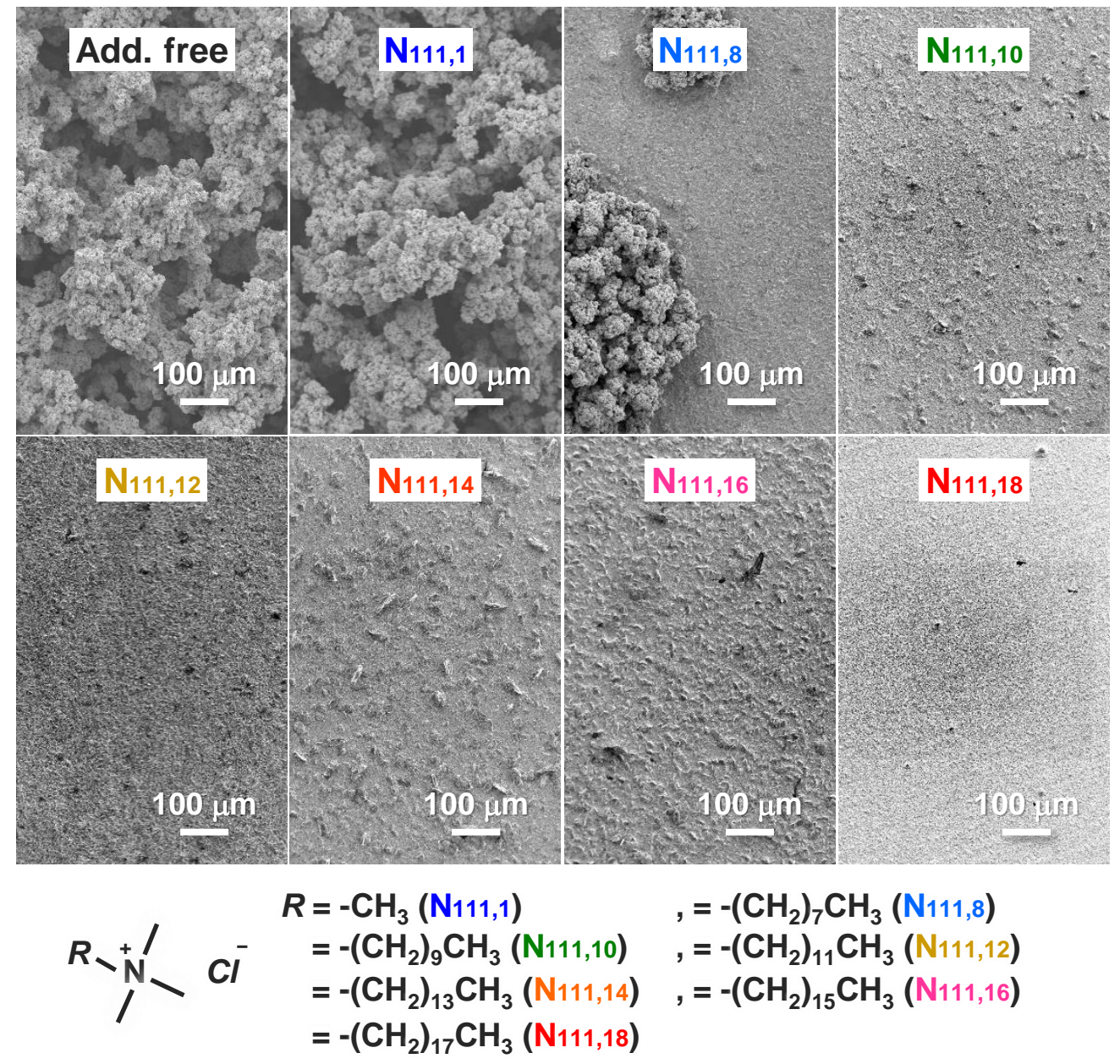

